\title{
ANALISIS PRODUKSI SAYURAN DALAM RANGKA PEMENUHAN KONSUMSI SAYURAN DI KOTA PEKANBARU PROVINSI RIAU
}

\author{
Elinur \\ Fakultas Pertanian Universitas Islam Riau \\ Email: elinurdjaimi@yahoo.com
}

\begin{abstract}
Demand vegetables in the city of Pekanbaru increased, but relatively similar vegetable production and a tendency to decline. This study aimed to analyze the dominant factors that determine the production of vegetables and return to scale of vegetables in Pekanbaru. Sampling metode was multi-stage random sampling with a sample of 44 vegetable farmers. The production function used is function cobb douglas with the estimation method Ordinary Least Square (OLS). Results of this researh revealed that, first: The dominant factor affecting vegetable production is labor, seed and fertilizer urea at 5 percent level of convidence and determination coefficient of 93.40 percent. Second, return to scale of vegetable farming was Decreasing Return to Scala (DRTS). This means that if the factors of production increased by 1 percent, the production of vegetables will increase by 0.985 percent. Third, the policy implications that must be done by the government in order to meet the demand of vegetables for the city of Pekanbaru made efforts to increase intensification.
\end{abstract}

Key words : Production vegetables, dominant factor, Decreasing Return to Scale and intensifikation

\section{PENDAHULUAN}

ayuran merupakan komoditas yang memiliki manfaat untuk kesehatan manusia. Beberapa jenis sayuran banyak mengandung gizi, vitamin dan banyak mengandung serat yang sangat baik untuk kesehatan manusia. Sayuran Bayam memiliki kandungan hampir 20 persen dari kebutuhan serat makanan untuk tubuh. Hal ini sangat baik untuk membantu pencernaan, mencegah sembelit, dan mengontrol kadar gula darah. Tanaman kangkung juga banyak mengandung vitamin dan kesehatan, diantaranya yaitu dapat mengatasi sembelit, imsomnia, dapat meningkatkan energi, bermanfaat untuk wanita 
(khususnya wanita monopouse), dan membantu pasien diabetes dengan masalah ginjal (Rukmana, 1994).

Disisi lain, komoditas sayuran juga bernilai ekonomis. Komoditas sayuran menjadi sumber pendapatan masyarakat dalam pemenuhan kebutuhan. Pengusahaan lahan untuk tanaman sayuran mudah diusahakan, berumur pendek (berkisar 24-30 hari) sehingga cepat menghasilkan dan hasil produksi sayuran cepat dierserap oleh pasar karena salah satu kebutuhan masyarakat yang yang penting. Oleh karena itu petani lebih memilih mengusahakan usahatani sayuran sebagai strategi untuk bertahan hidup (Marsudi, 2010).

Meningkatnya jumlah penduduk dan kesadaran masyarakat akan pentingnya mengkonsumsi sayuran serta kandungan gizi pada tiap jenis sayuran akan mendorong peningkatan konsumsi sayuran di Kota Pekanbaru. Berdasarkan data BPS Pekanbaru 2014 bahwa kebutuhan sayuran masyarakat Kota Pekanbaru sekitar $96 \mathrm{Kg} / \mathrm{kapita} /$ Tahun. Apabila itu jumlah penduduk pekanbaru sekitar 1.021 .710 jiwa, kebutuhan sayuran di Kota Pekanbaru sebesar 98.084, 16 ton per tahun.

Meningkatkan jumlah penduduk yang diiringi oleh meningkatnya konsumsi sayuran akan mendorong petani untuk meningkatkan produksi sayuran di Kota Pekanbaru. Perkembangan produksi dan luas lahan sayuran di Kota Pekanbaru menunjukkan peningkatan, namun peningkatannya tidak seimbangan dengan peningkatan konsumsinya. Data produksi dan luas lahan sayuran di Kota Pekanbaru disajikan pada Gambar 1.

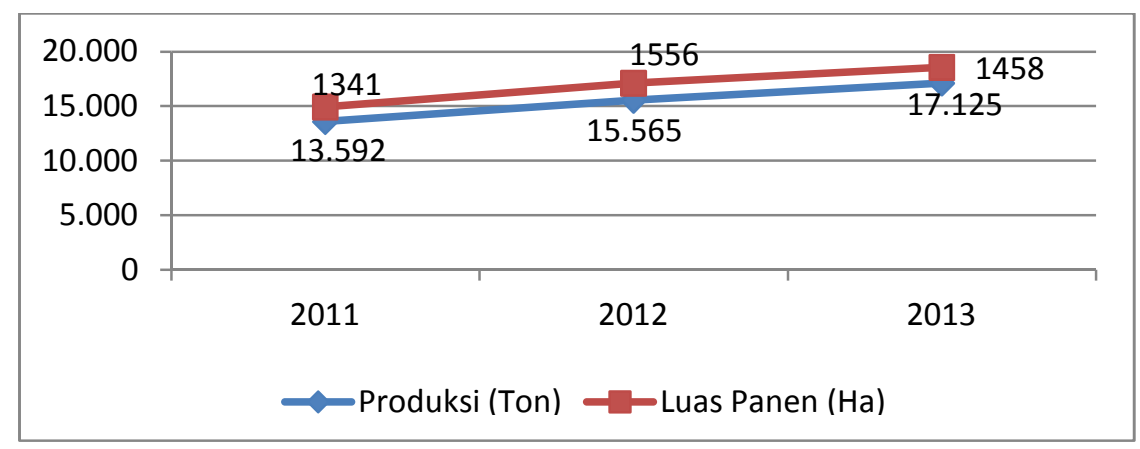

Sumber: BPS 2012- 2014

Gambar 1. Produksi dan Luas Lahan Sayur Bayam dan Kangkung di Kota Pekanbaru Tahun 2011 - 2013

QE Journal | Vol.05 - No. 03 September 2016 - 165 
Berdasarkan Gambar 1 dapat dijelaskan bahwa produksi dan luas panen sayuran di Kota Pekanbaru menunjukkan trend yang meningkat dengan perumbuhan rata-rata per tahun sebesar 10.893 persen per tahun. Sementara itu luas panen sayuran menunjukkan trend yang menurun dengan pertumbuhan 3.548 persen per tahun.

Dari fenomena data konsumsi dan produksi sayuran di Kota Pekanbaru menunjukkan konsumsi sayuran mengalami peningkatan dan produksinya juga demikian. Namun, peningkatan konsumsi sayuran lebih besar dari pada peningkatan produksi sayuran. Konsumsi dan produksi peningkatan rata-rata per tahun 23.203 persen dan 10.893 persen. Kesejangan antara konsumsi dan produksi sayuran tentu akan mengancam ketahanan pangan penduduk Kota Pekanbaru. Oleh karena itu, Pemerintah daerah mensuplai sayuran untuk memenuhi kebutuhan penduduk dengan mendatangkan sayuran dari daerah lain, dari kabupaten yang ada di Riau seperti Kabupaten Kampar atau dari provinsi tetangga, Sumatera Barat dan Utara. Disamping itu juga dilakukan upaya peningkatan produksi sayuran dengan cara intensifikasi dengan pengolahan tanah yang baik, menggunakan benih unggul, pupuk dan pembarantas hama dan penyakit tanaman. Dengan cara ini diharapkan dapat meningkatkan produksi sayuran di Kota Pekanbaru, sehingga kebutuhan pangan sayuran dapat terpenuhi dan tidak mengancam ketahanan pangan baik daerah maupun nasional.

Berdasarkan uraian yang telah dipaparkan, tujuan penelitian ini dalah untuk menganalisis faktor-faktor yang mempengaruhi produksi sayuran di Kota Pekanbaru. Disampin itu, penelitian ini juga menganalisis tingkat pengembalian hasil usaha sayuran di Kota Pekanbaru. Cakupan penelitian ini menganalisis komoditi sayuran bayam dan kangkung. Hal disebabkan petani mengusahakan sayuran tersebut lebih luas dan continue. Selain itu, sayuran tersebut banyak dikonsumsi oleh masyarakat dan harganya yang terjangkau.

Fungsi produksi menghubungkan input dengan output dan menentukan tingkat output optimum yang bisa diproduksi dengan sejumlah input tertentu atau sebaliknya, jumlah input minimum yang diperlukan untuk memproduksikan tingkat output tertentu. Fungsi produksi ditentukan oleh tingkat teknologi yang digunakan dalam proses produksi. Karena itu hubungan output input untuk suatu sistem produksi merupakan suatu 
fungsi dari tingkat teknologi pabrik, peralatan, tenaga kerja, bahan baku dan lain-lain yang digunakan dalam suatu perusahaan (Arsyad, 2003).

Fungsi produksi yang sering digunakan penelitian empiris adalah fungsi produksi Cobb-Douglas. Fungsi produksi Cobb-Douglas adalah suatu fungsi atau persamaan yang melibatkan dua atau lebih variabel, di mana variabel satu disebut variabel dependen $(Y)$ dan yang lain disebut variabel independen $(X)$. Penyelesaian hubungan antara $X$ dan $Y$ adalah biasanya dengan cara regresi, dimana variasi dari $Y$ akan dipengaruhi variasi dari $X$. Dengan demikian kaidah-kaidah pada garis regresi juga berlaku dalam penyelesaian fungsi Cobb-Douglas (Soekartawi, 2003).

Fungsi produksi Cobb-Dougals dapat ditulis sebagai berikut (Soekartawi, 2003):

$\mathrm{Y}=\mathrm{aX} X_{1}^{\mathrm{b} 1}, \mathrm{X}_{2}^{\mathrm{b} 2}, \ldots \ldots . \mathrm{X}_{\mathrm{n}}^{\mathrm{bn}} \mathrm{e}^{\mathrm{u}}$

dimana:

$\mathrm{Y}=$ Variabel yang dijelaskan

$\mathrm{X}=$ Variabel yang menjelaskan

$\mathrm{a}, \mathrm{b}=$ Besaran yang akan diduga

$\mathrm{e}=$ Kesalahan (disturbance term)

Persamaan (1) sering disebut fungsi produksi Cobb-Douglas (CobbDouglas production function). Fungsi Cobb-Douglas diperkenalkan oleh Charles W. Cobb dan Paul H. Douglas pada tahun 1920. Untuk memudahkan pendugaan terhadap persamaan di atas maka persamaan tersebut diperluas secara umum dan diubah menjadi bentuk linier dengan cara melogaritmakan persamaan tersebut (Soekartawi, 2003) yaitu:

$\log Y=\log a+b_{1} \log X_{1}+b_{2} \log X_{2}+b_{3} \log X_{3}+b_{4} \log X_{4}+e$

Penyelesaian fungsi Cobb-Douglas selalu dilogaritmakan dan diubah bentuknya menjadi linier, maka persyaratan dalam menggunakan fungsi tersebut antara lain: (1) tidak ada pengamatan yang bernilai nol. Sebab logaritma dari nol adalah suatu bilangan yang besarnya tidak diketahui (infinite); (2) dalam fungsi produksi perlu diasumsikan bahwa tidak ada perbedaan tingkat teknologi pada setiap pengamatan; dan (3) tiap variabel $\mathrm{X}$ dalam pasar perfect competition. Hasil pendugaan pada fungsi CobbDouglas akan menghasilkan koefisien regresi. Besarnya koefisien regresi

QE Journal | Vol.05 - No. 03 September 2016 - 167 
dari $b_{1}$ sampai $b_{4}$ pada persamaan 2 adalah angka elastisitas. Jumlah dari elastisitas adalah merupakan ukuran skala pengembalian hasil (returns to scale). Dengan demikian, kemungkinan ada 3 alternatif, yaitu:

- Decreasing returns to scale, bila $\left(\mathrm{b}_{1}+\mathrm{b}_{2}\right)<1$. Merupakan tambahan hasil yang semakin menurun atas skala produksi, kasus dimana output bertambah dengan proporsi yang lebih kecil dari pada input atau seorang petani yang menggunakan semua inputnya sebesar dua kali dari semula menghasilkan output yang kurang dari dua kali output semula.

- Constant returns to scale, bila $\left(\mathrm{b}_{1}+\mathrm{b}_{2}\right)=1$. Merupakan tambahan hasil yang konstan atas skala produksi, bila semua input naik dalam proporsi yang tertentu dan output yang diproduksi naik dalam proporsi yang tepat sama, jika faktor produksi di dua kalikan maka output naik sebesar dua kalinya.

- 3 Increasing returns to scale, bila $\left(\mathrm{b}_{1}+\mathrm{b}_{2}\right)>1$. Merupakan tambahan hasil yang meningkat atas skala produksi, kasus di mana output bertambah dengan proporsi yang lebih besar dari pada input. Contohnya bahwa seorang petani yang merubah penggunaan semua inputnya sebesar dua kali dari input semula dapat menghasilkan output lebih dari dua kali dari output semula.

Faktor produksi sering pula disebut dengan "korbanan produksi", karena faktor produksi tersebut diberikan kepada tanaman untuk mengasilkan produksi dengan baik. Faktor produksi sangat menentukan besar kecinya produksi yang dihasilkan Oleh karena itu untuk menghasilkan suatu produk, maka di perlukan input seperti lahan, modal untuk membeli bibit, pupuk, obat-obatan, tenaga kerja dan manajemen (Soekartawi, 2002). Seiring dengan Soekartawi (2002), Rahim dan Diah (2008) mengatakan faktor yang mempengaruhi produksi adalah lahan pertanian, tenaga kerja, modal, pupuk, Pestisida, teknologi, dan Manajemen.

Lahan pertanian merupakan penentu dari faktor produksi komoditas pertanian. Secara umum dikatakan, semakin luas lahan (yang digarap/ditanami), semakin besar jumlah produksi yang dihasil oleh lahan tersebut. Ukuran lahan dapat dinyatakan dengan hektar atau are. Di pedesaan, ukuran lahan petani menggunakan ukuran tradisonal, misalnya patok, jengkal dan kapling. Oleh karena itu, jika peneliti melakukan 
penelitian tentang luas lahan dapat dinyatakan melalui proses transformasi dari ukuran luas lahan trandisional ke dalam ukuran standar, yaitu hektar. Dalam penelitian ini luas lahan dinyatakan dalam meter persegi $\left(\mathrm{m}^{2}\right)$.

Tenaga kerja merupakan faktor penting dan perlu diperhitungkan dalam proses produksi komoditas pertanian. Tenaga kerja harus mempunyai kualitas berpikir yang maju seperti petani yang mampu mengadopsi inovasi-inovasi baru, terutama dalam menggunakan teknologi untuk pencapaian komoditas yang bagus sehingga nilai jual yang tinggi. Penggunaan tenaga kerja dapat dinyatakan sebagai curahan tenaga kerja. Curahan tenaga kerja adalah besarnya tenaga kerja efektif yang dipakai.

Usahatani yang mempunyai ukuran lahan berskala kecil biasanya disebut usahatani skala kecil dan biasanya menggunakan tenaga kerja dalam keluarga. Lain halnya dengan usahatani berskala besar. Selain menggunakan tenaga kerja luar keluarga, juga menggunakan tenaga ahli.

Ukuran tenaga kerja dalam usahatani dapat dinyatakan dalam hari orang kerja (HOK). Menurut Soekartawi (2002), dalam analisis ketenagakerjaan diperlukan standarisasi satuan tenaga kerja yang biasanya disebut hari kerja setara pria (HKSP).

Untuk memudahkan dalam menghitung tenaga kerja, maka sebagai patokan digunakan tenaga kerja pria dewasa. Sedangkan tenaga kerja wanita dan anak-anak dikonversikan kedalam tenaga kerja pria dewasa. Untuk satuan hari kerja pria (HKP) setara dengan $1 \mathrm{HKP}$ dan untuk tenaga kerja wanita sama dengan $0,8 \mathrm{HKW}$, sedangkan tenaga kerja anak-anak 0,5 HKP. Perhitungan ini berdasarkan atas lama kerja yakni 6-8 jam dalam satu hari (Soekartawi, 2002).

Pupuk merupakan tambahan dan pelengkap ketersediaan unsur hara dalam tanah. Tindakan pemupukan sangat mempengaruhi tingkat produktivitas. Kegiatan pemupukan harus memperhatikan hal-hal penting lainnya, seperti jenis tanah, umur dari tanaman itu sendiri dan faktor cuaca agar kegiatan pemupukan memberikan dampak yang paling maksimal.

Jenis pupuk yang sering digunakan adalah pupuk organik dan anorganik. Menurut Sutejo (2002), pupuk organic atau pupuk alam merupakan hasil akhir dari perubahan atau penguraian bagian-bagian atau sisa tanaman dan binatang, misalnya pupuk kandang, pupuk hijau, kompos, bungkil, guano dan tepung tulang. Sementara itu, pupuk anorganik atau pupuk

QE Journal | Vol.05 - No. 03 September 2016 - 169 
buatan merupakan hasil industry atau hasil pabrik-pabrik membuatan pupuk, misalnya pupuk urea, TSP dan $\mathrm{KCl}$.

Pestisida sangat dibutuhkan tanaman untuk mencegah serta membasmi hama dan penyakit yang menyerangnya. Pestisida merupakan racun yang mengandung zat-zat aktif sebagai membasmi hama dan penyakit pada tanaman.

Benih menentukan keunggulan dari suatu komoditas. Bibit yang unggul biasanya tahan terhadap penyakit, produksinya tinggi dan berkualitas dibandingkan dengan komoditas lain sehingga harganya dapat bersaing di pasar.

\section{METODE PENELITIAN}

Data diperoleh dengan menggunakan survey di tiga kecamatan dengan tiga kelurahan di Kota Pekanbaru, yaitu Kelurahan Sidomulyo Barat Kecamatan Tampan, Kelurahan Maharatu Kecamatan Marpoyan Damai dan Kelurahan Kulim Kecamtan Tenayan Raya. Hal ini dikarena ketiga lokasi tersebut merupakan daerah produksi sayuran di Kota Pekanbaru. Data yang diperlukan dalam penelitin ini adalah data primer dan data sekunder. Data primer dikumpulkan dengan menggunakan metode wawancara, yaitu mewawancarai langsung petani sayuran yang berpedoman pada daftar pertanyaan (kuesioner) yang telah dipersiapkan terlebih dahulu. Data primer yang dikumpulkan meliputi identitas petani (umur, pendidikan, jumlah anggota keluarga, pengalaman usahatani), penggunaan sarana produksi dan biaya yang digunakan dalam usahatani.

Data sekunder dikumpulkan menggunakan metode dokumenter, yaitu metode pengumpulan data dengan mengamati, mencari dan mengumpulkan dokumen-dokumen penting yang berhubungan dengan penelitian. Data sekunder yang dikumpulkan berupa produksi dan luas lahan sayuran, jumlah konsumsi sayuran jumlah petani sayuran dan lainlain. Sumber data sekunder diperoleh dari Dinas Tanaman Pangan dan Hortikultura, BPS dan instansi lain yang terkait.

Analisa data menggunakan fungsi produksi produksi Cobb-Douglas. Fungsi tersebut digunakan untuk, mengetahui faktor-faktor yang mempengaruhi produksi sayuran di Kota Pekanbaru. Model ini dipilih berdasarkan pertimbangan bahwa; (1) Model fungsi Cobb-Douglas adalah 
model yang lazim digunakan dalam penelitian ekonomi pertanian karena sifatnya yang praktis dan mudah ditrasformasikan ke dalam bentuk linear (Soekartawi, 2003); (2) Menurut Gujarati (2001) koefisien regresi yang ditunjukkan oleh fungsi produksi Cobb-Douglas merupakan elastisitas faktor produksi dan memberikan informasi mengenai pengaruh skala terhadap hasil (return to scale). Fungsi produksi Cobb-Douglas secara matematis dapat ditulis sebagai berikut:

$$
Y=\beta_{0} X_{1}^{\beta 1} X_{2}^{\beta 2} X_{3}^{\beta 3} X_{4}^{\beta 4} X_{5}^{\beta 5} X_{6}^{\beta 6} X_{7}^{\beta 7} e^{u i}
$$

Fungsi produksi Cobb Douglas merupakan fungsi produksi non linear. Agar memudahkan dalam mengestimasi dari masing-masing koefisien parameter peubah independen, maka diigunakan metode estimasi Ordinary Least Square (OLS). Apabila menggunakan metode estimasi OLS maka persamaan (1) dirubah bentuknya menjadi persamaan linear, sehingga model fungsi produksi Cobb-Douglas persamaan (1) dapat dirubah menjadi:

$$
\begin{aligned}
Y=\beta_{0}+\beta_{1} X_{1} & +\beta_{2} X_{2}+\beta_{3} X_{3}+\beta_{4} X_{4}+\beta_{5} X_{5} \\
& +\beta_{6} X_{6}+u_{i} \ldots \ldots \cdots \cdots \cdots \cdots . .
\end{aligned}
$$

dimana :

$\mathrm{Y}=$ Produksi Sayuran $(\mathrm{Kg} /$ produksi/garapan)

$\mathrm{X}_{1}=$ Luas tanam $\left(\mathrm{m}^{2}\right)$

$\mathrm{X}_{2}=$ Tenaga kerja (HOK)

$\mathrm{X}_{3}=\operatorname{Benih}(\mathrm{Kg})$

$\mathrm{X}_{4}=$ Pupuk Urea $(\mathrm{Kg})$

$\mathrm{X}_{5}=$ Pupuk Kandang $(\mathrm{Kg})$

$\mathrm{X}_{6}=$ Pestisida (Liter)

$\mathrm{B}_{0}-\mathrm{B}_{6}=$ Parameter pendugaan

Selanjutnya, menganalisis skala pengembalian hasil (Return to Skala). Skala pengembalian hasil terdiri dari Decreasing returns to scale (DRTS), Constant returns to scale (CRTS) dan Increasing returns to scale (IRTS). Sebagaimana yang tercantum pada Sugiarto (2007) dan Rahim dan Diah (2008) menunjukkan DRTS terjadi apabila kenaikan output dengan proporsi yang lebih kecil dari pada kenaikan input. DRS diperoleh dengan menjumlahkannilai parameter pendugaan $\beta_{1}+\beta_{2}+\beta_{3}+\beta_{4}+\beta_{5}<1$. CRTS adalah kenaikan output dan input dengan perbandingan yang sama. Apabila input naik dua kali maka output yang diproduksi akan naik 
sebesar dua kali juga. CRTS diperoleh dengan menjumlahkannilai parameter pendugaan $\beta_{1}+\beta_{2}+\beta_{3}+\beta_{4}+\beta_{5}=1$. IRTS adalah kenaikan output dengan proporsi yang lebih besar dari pada kenaikan input. Apabila input naik dua kali maka output yang diproduksi akan naik sebesar tiga atau empat kali. IRTS diperoleh dengan menjumlahkan nilai parameter pendugaan $\beta_{1}+\beta_{2}+\beta_{3}+\beta_{4}+\beta_{5}>1$.

\section{HASIL DAN PEMBAHASAN}

Penggunaan faktor-faktor produksi dalam usahatani sayuran di Kota Pekanbaru hanya dibatasi pada penggunaan jumlah tenaga kerja, benih, penggunaan pupuk urea, pupuk kandang dan pestisida. Sedangkan faktor produksi lahan tidak dimasukkan ke dalam model karena lahan diasumsikan sebagai factor produksi tetap dan karena petani sampel dalam menanam sayuran pada umumnya tidak menggunakan jarak tanam. Demikian halnya dengan factor produksi lain seperti kemampuan manajerial, tingkat teknologi tidak ikut diperhitungkan.

Hasil pendugaan model faktor produksi sayuran dalam penelitian ini sangat baik, sebagai mana terlihat dari koefisien determinasi $\left(R^{2}\right)$ yaitu 0,934. Hal ini menunjukkan bahwa 93,40 persen peubah jumlah produksi dapat dijelaskan oleh peubah jumlah tenaga kerja, penggunaan pupuk urea, penggunaan pupuk pupuk dan pestisida, sedangkan 16,60 persen dipengaruhi oleh peubah lain yang tidak termasuk dalam model. Variasi ini signifikan pada taraf nyata 10 persen yang dilihat dari F-hitung sebesar 107,277 dan probabilitas $<0,000$.

Hasil uji normalitas dengan menggunakan normal plot of Regression Standardized Residual menunjukkan bahwa model penggunaan factor produksi sayuran berdistribusi normal. Model regresi yang terbebas dari gejala multikolinieritas adalah memiliki nilai VIF kurang dari 10. Berdasarkan hasil uji multikolinieritas nilai VIF untuk semua peubah independen ( jumlah tenaga kerja, penggunaan pupuk urea, pupuk kandang dan pestisida) mempunyai nilai kurang dari 10 maka dapat disimpulkan bahwa tidak terjadi multikolinieritas pada model yang telah dibangun.

Nilai Durbin-Watson (DW) pada model yang dibangun yaitu sebesar 1,259 pada $\mathrm{n}=44$ dan $\mathrm{k}=6$. Dari Tabel distribusi DW dengan taraf nyata 1 persen 
di peroleh nilai dL sebesar 1,065 dan du sebesar 1,643, sehingga $d_{L}<d<4-d u$ $(1,065<\mathrm{d}<4-1,643)$. Hal ini berarti tidak terjadi autokorelasi.

Nilai koefisien regresi pada model fungsi produksi Cobb-Douglas merupakan elastisitas dari masing-masing peubah independen (jumlah tenaga kerja, penggunaan benih, pupuk urea, pupuk kandang dan pestisida). Elastisitas produksi diperoleh dari penjumlahan koefisien regresi peubah-peubah independen yang terdapat pada model. Hasil pendugaan model dan elsatisitas produksi sayuran dapat dilihat pada Tabel 1 sebagai berikut:

Tabel 1. Hasil Estimasi Parameter Fungsi Produksi Sayuran di Kota Pekanbaru Tahun 2015

\begin{tabular}{lllcl}
\hline No. & Peubah & Parameter Dugaan & $\operatorname{Pr}>|t|$ & VIF \\
\hline 1 & Intercept & 6.066 & 0.003 & 1.182 \\
2 & Tenaga Kerja & 0.056 & 0.029 & 3.727 \\
3 & Benih & 0.461 & 0.036 & 3.630 \\
4 & Pupuk Urea & 0.648 & 0.000 & 1.094 \\
5 & Pupuk Kandang & -0.163 & 0.387 & 1.059 \\
6 & Pestisida & -0.017 & 0.573 & 1.182 \\
\hline & $\mathrm{R}^{2}=0.934$, F-hitung $=107.277$ Prob.F $=<0.000$ & $\mathrm{DW}=1.259$ & \\
\hline
\end{tabular}

Hipotesis nol menyatakan bahwa peubah independen secara individu tidak mempengaruhi peubah dependen. Kriteria penolakan dan penerimaan hipotesis nol dijelaskan dengan membandingkan nilai $t$ statistik dengan $t$ tabel $(\operatorname{Pr}|t|)$. Penelitian ini menggunakan taraf nyata pada batas toleransi 10 persen. Taraf nyata diatas 10 persen dinyatakan tidak berbeda nyata dengan nol.

Hasil statistik $\mathrm{t}$ menunjukkan bahwa dua peubah independen yang tidak signifikan atau tidak berpengaruh nyata terhadap peubah dependen, yaitu peubah pupuk kandang dan pestisida. Tidak berpengaruhnya faktor-faktor produksi tersebut pada usahatani sayuran di Kota Pekanbaru disebabkan karena sebagian besar petani menggunakan pupuk kandang dan pestisida melebih yang direkomendasikan.

Hasil estimasi menunjukkan bahwa penggunaan jumlah tenaga kerja berpengaruh positif terhadap produksi sayuran dan berbeda nyata dengan nol pada taraf nyata 5 persen, sehingga hipotesis $\mathrm{H}_{0}$ ditolak dan hopotesis $\mathrm{H}_{\mathrm{a}}$ diterima. Artinya apabila jumlah tenaga kerja meningkat maka jumlah produksi juga meningkat. 
Koefisien tenaga kerja memiliki tanda positif yaitu sebesar 0,056 yang berarti bahwa setiap peningkatan 1 persen tenaga kerja akan meningkatkan jumlah produksi sebesar 0,056 persen. Demikian pula sebaliknya, setiap terjadi pengurangan 1 persen tenaga kerja, maka akan menurunkan jumlah produksi sebesar 0,056 persen dengan asumsi faktor produksi lainnya tetap. Pengaruh penggunaan tenaga kerja terhadap produksi bernilai positif sehingga dapat menaikkan produksi sayuran dengan melakukan peningkatan penggunaan tenaga kerja tanpa mengurangi penggunaan faktor produksi lain. Alokasi waktu kerja petani yang paling besar dalam usahatani adalah tenaga kerja pada waktu pengolahan lahan dan panen. Semakin besar alokasi kerja pada waktu pengolahan lahan dan panen maka produksi (hasil panen) cenderung meningkat.

Hasil estimasi yang diperoleh menunjukkan bahwabenih berpengaruh positif terhadap jumlah produksi sayuran dan berbeda nyata dengan nol pada taraf nyata 5 persen sehingga hipotesis $\mathrm{H}_{0}$ ditolak dan hopotesis $\mathrm{H}_{a}$ diterima. Artinya apabila benih meningkat maka jumlah produksi juga meningkat.

Koefisien benih memiliki tanda positif yaitu sebesar 0,461 yang berarti bahwa setiap peningkatan 1 persen benih akan meningkatkan jumlah produksi sayuran sebesar 0,461 persen. Demikian pula sebaliknya, setiap terjadi pengurangan 1 persen benih, maka akan menurunkan jumlah produksi sayuran sebesar 0,461 persen dengan asumsi faktor produksi lainnya tetap. Pengaruh penggunaan benih terhadap produksi bernilai positif sehingga dapat menaikkan produksi sayuran dengan melakukan peningkatan penggunaan benih tanpa mengurangi penggunaan faktor produksi lain.

Hasil estimasi yang diperoleh menunjukkan bahwa pupuk urea berpengaruh positif terhadap jumlah produksi sayuran dan berbeda nyata dengan nol pada taraf nyata 1 persen sehingga hipotesis $\mathrm{H}_{0}$ ditolak dan hopotesis $\mathrm{H}_{a}$ diterima. Artinya apabila pupuk urea meningkat maka jumlah produksi sayuran juga meningkat.

Koefisien pupuk urea memiliki tanda positif yaitu sebesar 0,648 yang berarti bahwa setiap peningkatan 1 persen pupuk urea akan meningkatkan jumlah produksi sayuran sebesar 0,648 persen. Demikian pula sebaliknya, setiap terjadi pengurangan 1 persen pupuk urea, maka akan menurunkan 
jumlah produksi sebesar 0,648 persen dengan asumsi faktor produksi lainnya tetap. Pengaruh penggunaan pupuk urea terhadap produksi bernilai positif sehingga dapat menaikkan produksi sayuran dengan melakukan peningkatan penggunaan pupuk urea tanpa mengurangi penggunaan faktor produksi lain.

Skala pengembalian hasil merupakan bagian yang penting dalam analisis fungsi produksi. Skala pengembalian hasil menunjukkan hubungan perubahan input secara bersama-sama (dalam persentase) terhadap perubahan output. Berdasarkan hasil penelitian diperoleh total nilai parameter pendugaan penggunaan input tenaga kerja, benih, pupuk urea, pupuk kandang dan pestisida ( $\Sigma \beta i$ ) sebesar 0.985. Nilai tersebut menunjukkan bahwa skala pengembalian hasil usahatani sayuran di Kota Pekanbaru tergolong dalam Decreasing Return to Scala (DRTS). Artinya proporsi kenaikan output lebih kecil dari pada kenaikan input, atau apabila faktor-faktor produksi (tenaga kerja, benih, pupuk urea, pupuk kandang dan pestisida) dinaikkan sebesar 1 persen maka produksi sayuran akan meningkat sebesar 0,985 persen.

\section{KESIMPULAN DAN SARAN}

\section{Kesimpulan}

Berdasarkan hasil peneltian menunjukkan bahwa faktor dominan yang mempengaruhi produksi sayuran di Kota Pekanbaru adalah tenaga kerja, banih dan pupuk urea pada taraf kepercayaan $(\alpha) 5$ persen. Koefisien regresi $\left(R^{2}\right)$ sebesar 93,40 persen. Nilai koefisien tersebut memiliki arti bahwa peubah independen dapat menjelaskan variasi peubah produksi sayuran sebesar 93,40 persen dan sisanya 2,1 persen dijelaskan oleh variabel lain yang tidak dimasukkan kedalam model yang diwakilkan oleh error term.

Skala pengembalian hasil (RTS) usahatani sayuran di Kota Pekanbaru tergolong dalam Decreasing Return to Scala (DRTS), dengan nilai $\sum \beta \mathrm{i}$ sebesar 0.985. Nilai tersebut bemakna apabila faktor-faktor produksi (tenaga kerja, benih, pupuk urea, pupuk kandang dan pestisida) dinaikkan sebesar 1 persen maka produksi sayuran akan meningkat sebesar 0,985 persen. 


\section{Saran}

Seiring dengan berjalannya waktu, konsumsi sayuran cenderung mengalami peningkatan karena jumlah penduduk yang meningkat dan kesadaran masyarakat akan pentingnya sayuran untuk kesehatan. Sementara itu, peningkatan produksi sayuran tidak mengalami peningkatan yang lebih besar atau sama dengan produksi. Kesenjangan produksi dan konsumsi sayuran menyebabkan terjadinya kekurangan sayuran. Ketersedian sayuran yang tidak mencukupi akan menyebabkan harga sayuran semakin mahal. Mengatasi Kondisi ini perlu upaya peningkatan produksi sayuran dengan cara intensifikasi. Usaha intensifikasi dilakukan dengan cara meliputi:

a) Penanamana varietas unggul dan perbaikan teknik budidaya. Penanaman sayuran dengan menggunakan bibit unggul melalui penanaman varietas/galur unggul yang sesuai dengan agroekologi dan perbaikan teknik budidaya. Peningkatan produktivitas sayuran menggunakan bibit unggul mencapai 14 -16 ton/hektar. Kenyataannya petani masih menggunakan benih lokal dengan harga yang terjangkau oleh petani.

b) Penggunaan pupuk berimbang dan pemberantasan hama dan penyakit tanaman. Kenyataannya menunjukkan petani menggunanakan pupuk belum sesuai yang direkonmendasikan. Oleh karena itu perlu petugas penyuluhan pertanian untuk memantau dan mengarahkan kegiatan usahatani sayuran. Kenyataan selama ini petani sayuran tidak diberi penyuluhan dan bercocok tanaman sesuai kemampuannya sendiri.

c) Perlu adanya pemberdayaan kelembagaan usahatani sayuran, seperti membinaan kelompoktani, pembiayaan usahani dan penyuluhan pertanian

\section{DAFTAR PUSTAKA}

Badan Pusat Statistik. 2012. Pekanbaru Dalam Angka. Badan Pusat Statistik Pekanbaru.

Badan Pusat Statistik. 2013. Pekanbaru Dalam Angka. Badan Pusat Statistik Pekanbaru.

Badan Pusat Statistik. 2014. Pekanbaru Dalam Angka. Badan Pusat Statistik Pekanbaru. 
Marsudi, E. 2014. Analisis Pendapatan Beberapa Usahatani Sayuran di Kabupaten Pidie. Jurnal Sain Riset 1 (3): 34 - 39.

Rahim, A dan Diah R.D.H. 2008. Ekonomika Pertanian: Pengantar, Teori dan Kasus. Penebar Swadaya, Jakarta.

Rukmana. 1994. Kangkung. PT. Kannisius, Jakarta.

Sugiarto, T. Herlambang, Brastoro, R. Sudjana dan S. Kelana. 2007. Ekonomi Mikro: Sebuah Kajian Konprehensif. PT. Gramedia Pustaka Utama, Jakarta.

Soekartawi. 2003. Agribisnis Teori dan Aplikasinya. PT Raja Grafindo Persada, Jakarta. 